\title{
The first scarabaeid beetle (Coleoptera, Scarabaeidae, Melolonthinae) described from the Mesozoic (Late-Cretaceous) of Africa
}

\author{
Christopher Woolley' \\ I Evolutionary Studies Institute, University of the Witwatersrand, Johannesburg, Gauteng, Wits 2050, South Africa \\ Corresponding author: Christopher Woolley (christopher.woolley@wits.ac.za)
}

Academic editor: P. Stoev | Received 10 March 2016 | Accepted 14 April 2016 | Published 6 June 2016

http://zoobank.org/9AE415AB-300C-4129-A21B-A33590DC5B42

Citation: Woolley C (2016) The first scarabaeid beetle (Coleoptera, Scarabaeidae, Melolonthinae) described from the Mesozoic (Late-Cretaceous) of Africa. African Invertebrates 57(1): 53-66. doi: 10.3897/AfrInvertebr.57.8416

\begin{abstract}
A full description is given of the first scarabaeid beetle documented from the Mesozoic (Late Cretaceous) of Africa (Orapa, Botswana). Brief and partial descriptions of this beetle have appeared in two previous review papers of fossils from the Orapa Diamond Mine. This work represents an updated analysis and interpretation of the fossil based on character comparison and phylogenetic analysis. The new genus and species, Ceafornotensis archratiras, are described in Melolonthinae incertae sedis. Phylogenetic analysis suggests a sister group relationship with the tribe Phaenognathini (Melolonthinae incertae sedis). Although phytophagy in the adult beetle cannot be confirmed, it is proposed that angiosperms could have contributed to a proportion of its diet (larval or adult). This beetle may belong to a stem lineage of pleurostict scarabaeids which later experienced major radiation in response to widespread environmental changes brought about by continuing radiation of the angiosperms.
\end{abstract}

\section{Keywords}

Scarabaeoidea, scarab, palaeoenvironment, Turonian, Late Cretaceous, Mesozoic, Botswana, Orapa, diamond mine, crater lake

Copyright Christopher Woolley. This is an open access article distributed under the terms of the Creative Commons Attribution License (CC BY 4.0), which permits unrestricted use, distribution, and reproduction in any medium, provided the original author and source are credited. 


\section{Introduction}

Compression fossils of insects from the Orapa Diamond Mine (Central District, Botswana, $21^{\circ} 18.465^{\prime} \mathrm{S} ; 25^{\circ} 22.177^{\prime} \mathrm{E}$ ) are known for their excellent preservation (Rayner 1993). The relative scarcity of Cretaceous deposits in the Southern Hemisphere, lends Orapa particular importance amongst the known lagerstätte (Rasnitsyn and Brothers 2007). The deposit's age, estimated at 91 mya (Turonian age $-89.0 \pm 0.5$ to 93.5 \pm 0.2 mya), (Brothers and Rasnitsyn 2003; Davis 1977; Haggerty et al. 1983), is also significant with respect to the angiosperms and their contemporaneous radiation (Rayner et al. 1997).

The insects' burial and preservation is thought to have come about through the infilling of a crater lake by mass flows of epiclastic material from the crater's sides (Rayner et al. 1991). That a large assemblage of aquatic insects is not found in the deposits has led to the suggestion that volcanic leachates produced inimical conditions for life in the lake's waters (McKay and Rayner 1986). Insects that were buried in lake sediments are therefore thought to be those which either fell into the lake or alighted on the surface before becoming trapped. Toxic leachates could also account for the absence of trace fossils (McKay and Rayner 1986) and reduced bioactivity may have limited decomposition thereby further enhancing the preservation of these fossils.

The presence of deciduous leaves, together with a southerly shift in the presentday distributions of several taxa: Empidae (Waters 1989), Bibionidae (Rayner 1987), Promecognathinae (McKay 1990), suggest that the palaeoclimate of Orapa was both seasonal, and cooler and wetter than found today. Plant remains are predominately from angiosperms and the diversity of leaf types (entire and serrated margins) suggest a mixed successional vegetation within the crater being periodically disturbed by mass flows from the unstable slopes. Mesic forest may have predominated over the wider area contrasting with sparser and earlier successional vegetation on the crater sides (Bamford 1990). Sedimentology, dating methodology, palaeoenvironment and selected references to the fossil flora and fauna are dealt with by McKay and Rayner (1986), Rayner et al. (1991), Rayner (1993) and Rayner et al. (1997).

Coleoptera, which account for approximately one third of the Orapa specimens, have so far been addressed in two papers, one describing a ground beetle Palaeoaxinidium orapensis McKay, 1991 (Promecognathinae, Carabidae) (McKay 1991), and another, a weevil Orapaeus cretaceous Kuschel \& Oberprieler, 1994 (Brentidae, Curculionoidea) (Kuschel et al. 1994), together with a doctoral thesis on the Carabidae (McKay 1990).

The Orapa collection holds two fossil specimens belonging to the superfamily Scarabaeoidea (= Lamellicornia). The fossil described in this paper has been documented in a review of the Orapa fossils in McKay and Rayner (1986) and Rayner et al. (1997). A brief description and photograph was provided in the former publication with reference to its likely placement within the family Scarabaeidae. In the latter publication, it was suggested that the fossil may be that of a dung beetle (Scarabaeinae). In the following interpretation it is argued that this specimen is more likely of the 
'pleurostict' lineage (McKenna et al. 2015) and could belong to the Melolonthinae, a large and diverse family which includes 'chafers' and 'maybugs'.

The described specimen (BP/2/18654) is housed in the collection at the Evolutionary Studies Institute, University of the Witwatersrand.

\section{Taxonomy}

\section{Family Scarabaeidae \\ Sub-family Melolonthinae}

\section{Genus Ceafornotensis gen. n.}

http://zoobank.org/B6C43D03-2660-4A2C-BB53-BE9FF6501D79

Etymology. From Old English ceafor (chafer) and Greek notius (south).

Type species. Ceafornotensis archratiras sp. $\mathrm{n}$.

Diagnosis. The placement of the fossil beetle within the superfamily Scarabaeoidea is based on the following synapomorphies as referred to in Krell (2006); antennae with a lamellate club; pronotum and forelegs adapted for burrowing; protibae dilated apically.

Character comparison. The specimen differs from Glaresidae, Lucanidae, Passalidae, Trogidae by six visible sternites; from Diphyllostomatidae, Ochodaeidae by partially division of the eye by a genal lobe, apical spurs of the tibae not serrate; from Pleocomidae by developed mouthparts; from Glaphyridae by broad pronotum (not subquadrate), elytra long in form, covering most of the abdomen; from Bolboceratidae, Geotrupidae, Glaphyridae, Hybosoridae by protibia with a single tooth to outer margin, tibia outer margin not serrate, parameres long relative to basal piece and symmetrical to subsymmetrical, median lobe absent or reduced. Additionally, left mandible broad and dentate, not sickle shaped, the form unlikely to accommodate a well-developed mesal brush, antennae lamellae without cupule, would omit the specimen from the Hybosoridae to which the habitas of the specimen otherwise closely resembles.

Of the subfamilies of the Scarabaeidae, the specimen differs from Scarabaeinae, by two spurs on the metatibia, middle coxae contiguous, scutellum well developed; from Aphodiinae, Allidiostomatinae, Orphninae by spurs close-set, not separated by basal tarsomere; from Cetoniinae by short clypeus, not restricted in width before eyes, mandibles broad and dentate, the form unlikely to accommodate a well-developed mesal brush; from Rutelinae by metatarsal claws symmetrical, small, apical tarsomere not enlarged and lengthened; from Dynastinae by pronotum and clypeus simple, lacking major protuberances, foveae or carinae.

The presence of minor pronotal or cephalic armature cannot be discounted and pronounced dimorphic features are not present in all tribes (e.g. Cyclocephalini) or may exhibit intra-specific variation. From the existing fossil record and divergence 
time estimates (Ahrens et al. 2014; Krell 2006), the Dynastinae are thought to have diverged from the Rutelinae during the Palaeogene. On the balance of available evidence the placement of the specimen within the Dynastinae is thought unlikely.

From Mesozoic taxa the specimen differs from Cretoscarabaeinae, Lithoscarabaeidae, Holcorobeini (Nikolajev 1998) and Cretorabaeus Nikolajev, 1995 (Nikolajev 1995) by meso-, metatibia bearing a single transverse carina; from the Mesozoic genera of the tribe Sercini; Lithanomala Nikolajev, 1992 and Cretoserica Nikolajev, 1998 (Nikolajev 1998) by apical spurs close-set, not separated by basal tarsomere. Nikolajev erected the family Cretomelolonthinae (Nikolajev 1998; Nikolajev 2007) based on four specimens of Cretomelolontha transbaikalica Nikolajev, 1998, from the Baissa locality, Lower Cretaceous. Although some characters are common to the Orapa specimen; spur at mid and hind tibial apices close-set, mid and hind tibae with one transverse carina, the Baissa specimen possesses features of the wing which cannot be corroborated; wings are not preserved in the Orapa specimen although the form and humeral development would suggest that the beetle was capable of flight. Other characters could be considered plesiomorphic. The Orapa specimen differs by broader tarsomeres relative to the width of the tibial apices, and the longer length of the parameres relative to the basal piece (membrane).

The paucity of apomorphies (Browne and Scholtz 1998), and that the phylogeny of the Melolonthinae is considered paraphyletic (Ahrens 2006) and unresolved (Jameson and Ratcliffe 2000) makes the placement of fossils into this subfamily problematic. However, lack of support for the specimen's inclusion outside of the 'higher scarabs' together with relative length of the parameres to the basal piece (Fig. 4c), elongate and narrow antennal lamellae and evidence from the fossil record, give support for the specimen's placement within the Melolonthinae.

Systematic phylogeny: Phylogenetic analysis was performed using the character set from Bai et al. (2011). Included in the analysis are 20 species comprising 12 families of the Scarabaeoidea, a fossil specimen from Yixian Formation, Prophaenognatha robusta Bai et al., 2011 described in Bai et al. (2011), the Orapa specimen and three outgroup species comprising three families of the Hydrophiloidea (Hydrophilidae, Histeridae, Synteliidae). Of the 68 characters in the character set, 27 could be identified with confidence in the Orapa specimen (Table 1). As in Bai et al. (2011), heuristic searches and a bootstrap analysis were performed in Winclada/Nona with the same parameter settings. A strict consensus tree (Fig. 1) was derived from six most parsimonious trees. The phylogeny obtained from the analysis is similar to that in the original study with divisions of higher taxa poorly supported but good support for family groups (see bootstrap values Fig. 1). In the strict consensus tree, the relationship between several families could not be resolved. The Orapa specimen was placed within this polytomy with moderate support as a sister taxa to the Phaenognathini which includes the Yixian fossil $P$. robusta (Fig. 1). The position of the Orapa fossil in the phylogeny is supported by two character states; antennal club loose, and outer apical angle of protibia simple or slightly produced.

The close relationship between Ochodaeidae and the Hybosoridae, which is supported in both morphological (Browne and Scholtz 1999; Scholtz et al. 1988) and 
Table I. List of 27 characters identified in the Orapa fossil for phylogenetic analysis (Fig. 3). The full characters set of 68 characters is given in Bai et al. (2011). Character numbers in the left column refer to the full character set. Characters state for the specimen is given in parentheses in the left column.

\begin{tabular}{|c|c|}
\hline $\begin{array}{l}\text { Character \# } \\
\text { and state }\end{array}$ & Character and states \\
\hline $4(1)$ & Eyes canthus: (0) absent; (1) present \\
\hline $7(1)$ & Antenna club: (0) not lamellate; (1) lamellate \\
\hline $9(2)$ & $\begin{array}{l}\text { Antenna club: (0) 1-segmented; (1) 2-segmented; (2) 3-segmented; (3) 4-segmented; (4) } \\
\text { 5-segmented; (5) with } 6 \text { or more segments }\end{array}$ \\
\hline $10(0)$ & Antennal club: (0) loose; (1) compact \\
\hline $11(1)$ & Antennal club: (0) not or slightly flattened; (1) distinctly flattened \\
\hline $12(0)$ & Antennal club: (0) not preceded by cupule; (1) preceded by cupule \\
\hline $13(0)$ & $\begin{array}{l}\text { Apex of labrum: (0) subtruncate to slightly convex; (1) strongly convex, narrowly rounded or } \\
\text { acute; (2) slightly concave or emarginate; (3) deeply emarginate or bilobed; (4) trilobed or with } \\
\text { several lobes or teeth }\end{array}$ \\
\hline $14(1)$ & $\begin{array}{l}\text { Mandibular apex: (0) not or slightly and gradually curved mesally; (1) moderately to strongly, } \\
\text { gradually curved mesally; (2) strongly and abruptly curved mesally }\end{array}$ \\
\hline $15(0)$ & $\begin{array}{l}\text { Mandibular apex: (0) unidentate, truncate or rounded; (1) bidentate or biolobed; (2) multidentate } \\
\text { or multilobed }\end{array}$ \\
\hline $22(2)$ & Prothorax widest: (0) anteriorly; (1) at middle; (2) posteriorly \\
\hline $23(2)$ & $\begin{array}{l}\text { Sides of prothorax: (0) more or less straight; (1) moderately to strongly curved; (2) straight } \\
\text { posteriorly, curved anteriorly; (3) sinuate; (4) variously lobed }\end{array}$ \\
\hline $25(1)$ & Anterior angles of pronotum: (0) absent or not produced forward; (1) distinctly produced forward \\
\hline $26(2)$ & $\begin{array}{l}\text { Anterior angles of pronotum: (0) absent, right or rounded, not produced; (1) produced and } \\
\text { broadly rounded or obtusely angulate; (2) produced and narrowly rounded or acute }\end{array}$ \\
\hline $27(1)$ & $\begin{array}{l}\text { Posterior angles of pronotum: (0) absent or broadly rounded; (1) obtuse or right; (2) moderately } \\
\text { to strongly acute }\end{array}$ \\
\hline $39(0)$ & Scutellum: (0) well developed; (1) highly reduced; (2) absent or not visible \\
\hline $46(0)$ & Metacoxae: (0) contiguous or narrowly separated; (1) widely separated \\
\hline $54(0)$ & Metafemur (0) not much wider than mesofemur; (1) much wider than mesofemur \\
\hline $55(0)$ & $\begin{array}{l}\text { Mesotibia: (0) not strongly widened; (1) strongly widened, widest at or near apex; (2) strongly } \\
\text { widened, widest well before apex }\end{array}$ \\
\hline $56(1)$ & $\begin{array}{l}\text { Preapical surfaces of mesotibia: }(0) \text { without ridges or combs; (1) with transverse or oblique ridge } \\
\text { or combs }\end{array}$ \\
\hline $57(0)$ & $\begin{array}{l}\text { Outer apical angles of mesotibia: (0) simple or slightly produced, without lobe, teeth or spines; (1) } \\
\text { with one or more straight or outwardly facing teeth or spines: (2) with rounded lobe or process } \\
\text { bearing spines }\end{array}$ \\
\hline $58(1)$ & $\begin{array}{l}\text { Outer edge of protibial: (0) simple or rounded to carinate but without lobes or teeth except at } \\
\text { apex; (1) with one or more distinct lobes or teeth }\end{array}$ \\
\hline $59(2)$ & $\begin{array}{l}\text { Outer apical angle of protibial: (0) simple or slightly produced, without lobe, teeth or spines; (1) } \\
\text { with one or more straight or outwardly facing teeth or spines; (2) with rounded lobe or process } \\
\text { sometimes bearing spines }\end{array}$ \\
\hline $60(2)$ & Protibial spurs: (0) single; (1) double; (2) absent \\
\hline $61(1)$ & $\begin{array}{l}\text { Preapical surfaces of metatibia (0) without ridges or combs (1) with transverse or oblique ridge or } \\
\text { combs }\end{array}$ \\
\hline $62(0)$ & $\begin{array}{l}\text { Metatibial articular area: (0) not to only moderately expanded, narrowly oval or oblique; (1) } \\
\text { greatly expanded, broadly oval to circular and flattened }\end{array}$ \\
\hline $63(1)$ & $\begin{array}{l}\text { Metatibial spurs: (0) subequal in length and form; (1) differing distinctly in length; (2) differing } \\
\text { distinctly in form }\end{array}$ \\
\hline $64(3)$ & Number of abdominal ventrites: (0) 3; (1) 4; (2) 5; (3) 6; (4) 7 \\
\hline $66(0)$ & First ventrite: $(0)$ not completely divided by metacoxae; (1) divided into 2 or 3 parts of metacoxae \\
\hline
\end{tabular}




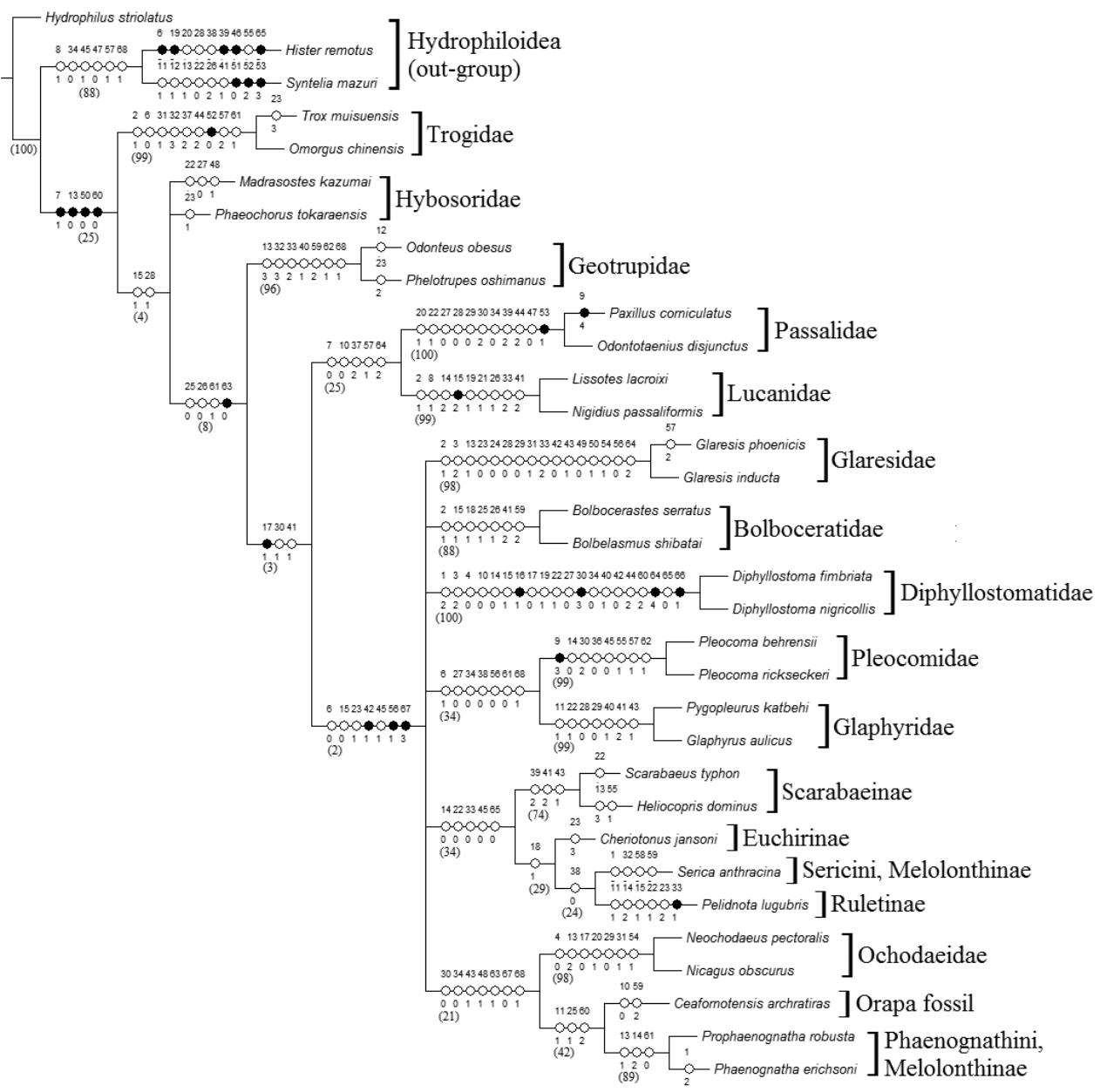

Figure I. Strict consensus of six most parsimonious trees showing characters (above) and state (below). Bootstrap support values are given in parentheses (tree length $=275$ steps, ensemble consistency index $(\mathrm{CI})$ $=0.39$, ensemble retention index $(\mathrm{RI})=0.64)$. . . archratiras is referred to as "Orapa fossil". Character set from Bai et al. (2011).

molecular-based phylogenies (Ahrens et al. 2014; Smith et al. 2006), was not apparent in the strict consensus tree and may suggest that the placement of Ochodaeidae as a sister taxa to the Phaenognathini is erroneous. The Phaenognathini, recently established by Ocampo and Mondaca (2012), contains the genera Phaenognatha Hope, 1845 and Neophaenognatha Allsopp, 1983 formerly placed within the Aclopinae. The position of the Phaenognathini within the Melolonthinae remains unclear although Ocampo and Mondaca (2012) have hypothesised a relationship between the Phaenognathini and the Lichniini suggesting that they may "constitute a distinct and ancient lineage of Scarabaeidae". Evidence from a preliminary molecular analysis (Smith et al. 2006) 
indicates that several smaller taxa belong within a Melolonthinae clade or 'grade'. These taxa include Lichniini, removed from the Glaphyridae (Hawkins, 2006), and subfamilies of the Scarabaeidae; Aclopinae, Allidiostomatinae, Euchirinae, Orphninae and Pachypodinae. The paraphyletic grade of the Melolonthinae is also supported by recent studies (Ahrens et al. 2014; McKenna et al. 2015). Given the uncertainties of the current phylogeny, the Orapa specimen is placed as Melolonthinae incertae sedis.

\section{Ceafornotensis archratiras sp. $\mathbf{n}$.}

http://zoobank.org/252F8466-8734-4554-AF63-D2B8EB264742

Figs 2, 3, 4

Etymology. A combining of Greek archaios (ancient) and Greek kratiras (crater) in reference to the crater lake origin of this specimen.

Description. medium-sized oval body, mandibles and labrum exposed beyond clypeus, left mandible short, dentate with single acute apical tooth, broad subapical tooth and distinct molar region, outer margin abruptly angled mesally, clypeus trapezoidal, eye partially divided by genal lobe, antennal club with three lamellae, lamellae elongate and narrow, pronotum broad, protibia with single lateral tooth mesally, metatibia with single transverse carina mesally, metatibial apex with 2 spurs, spurs adjacent, unequal in length, 'inner' spur extending just beyond tarsomere 1, 'outer' spur extending just beyond tarsomere 2 , tarsomeres 1,2 , broad, not elongate, metatibia with single transverse carina mesally, metatibial apex with 2 spurs, spurs adjacent, unequal in length, 'inner' spur extending to tarsomere 2, 'outer' spur extending to tarsomere 3, tarsomeres 1,2 , broad, not elongate, mid and hind coxae contiguous, six visible sternites, terminal sternite exposed beyond elytra, median lobe of aedeagus absent/reduced, parameres long relative to basal piece.

Measurements (mm). body length from mandible apex to terminus of abdomen, 11.64; mandible length, 0.77 ; labrum length, 0.26 ; labrum width, 0.72 ; clypeal width 1.64; width between eye orbits, 1.69; Length of lamellae, 0.69; pronotal width, 4.71; humeral width, 4.87; elytron length, 6.25; elytron width, 2.82; profemur width, 1; profemur length, 2.15; protibial length, 1.97; mesofemur width, 0.92; mesotibial length, 1.59; mesotibial width at apex, 0.51; mesotibial spur length, inner 0.38, outer 0.87; length of mesotarsal segment 2, 0.36; Width of mesotarsal segment 2, 0.26; metafemur width, 0.92/1.02; metatibial length, 2.31; metatibia width at apex, 0.71; metatibial spur length, inner 0.87 , outer 1.33 ; length of metatarsus, 2.31 ; length of metatarsal segments $1,0.4 ; 2,0.38 ; 3,0.46 ; 4,0.38 ; 5,0.61$ (without claws 0.41 ) ; length of metatarsal segments $2,0.31 ; 3,0.21 ; 4,0.13 ; 5,0.13$; length of basal piece 0.76 ; length of parameres 0.71 .

Holotype. BP/2/18654 BOTSWANA: Central District: Orapa Diamond Mine, $21^{\circ} 18^{\prime} 27.9^{\prime \prime S}, 25^{\circ} 22^{\prime} 10.6^{\prime E}$; Late Crateous, Turonian, Orapa epiclastic kimberlite. 


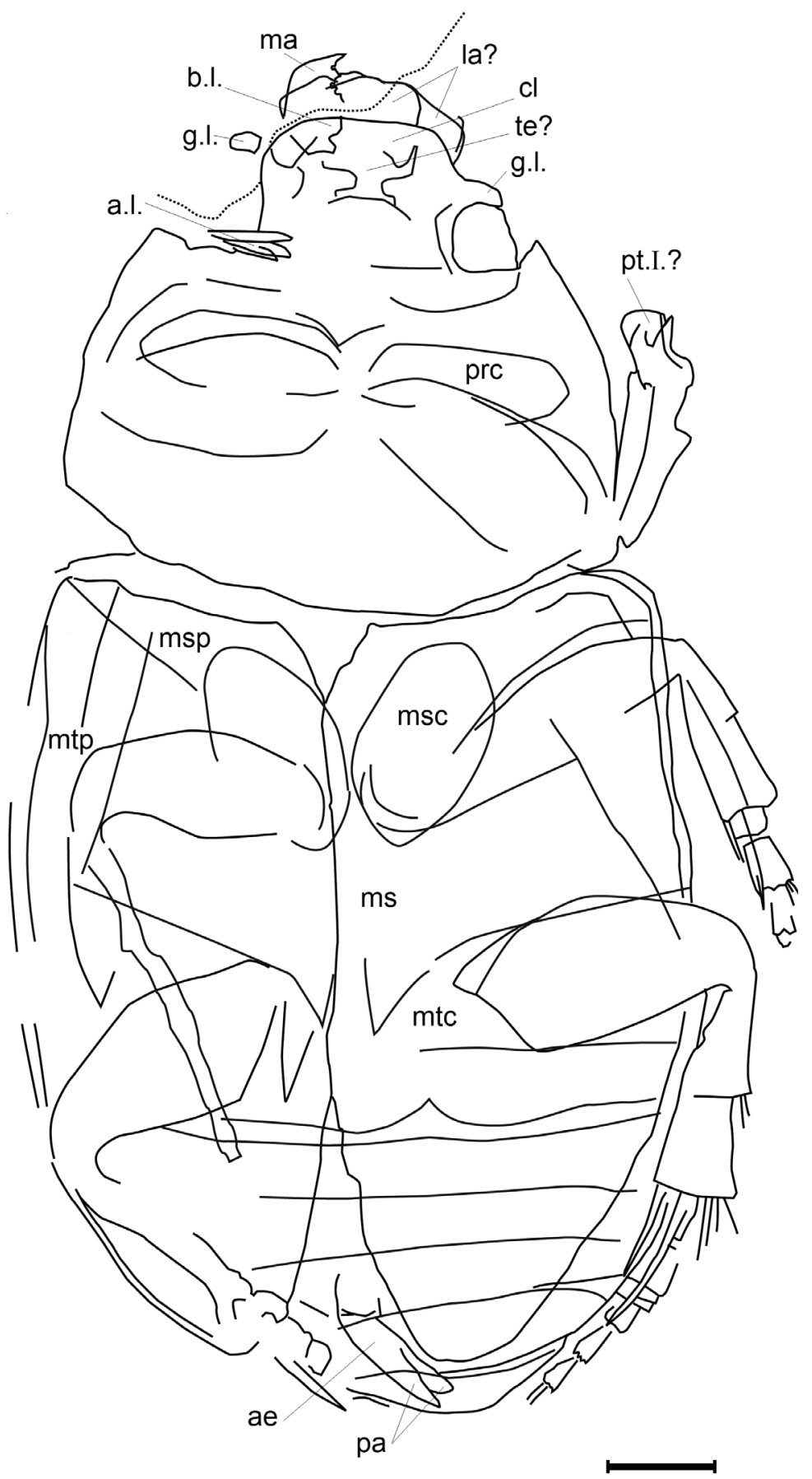

Figure 2. Ceafornotensis archratiras gen. and sp. n.: holotype BP/2/18654, habitus. Abbreviations: ae aedeagus, a.l. - antennal lamellae, b.l. - basal lobe of mandible, cl - clypeus, g.l. - genal lobe, la? - labrum?, ma - mandible, ms - metasternum, msc - mesocoxa, msp - mesopisternum, mtc - metacoxa, mtp - metepisternum, pa - parameres, prc - procoxa, pt. I.? - protarsus I?, te? - tentorium?. Scale bar: $1 \mathrm{~mm}$. 

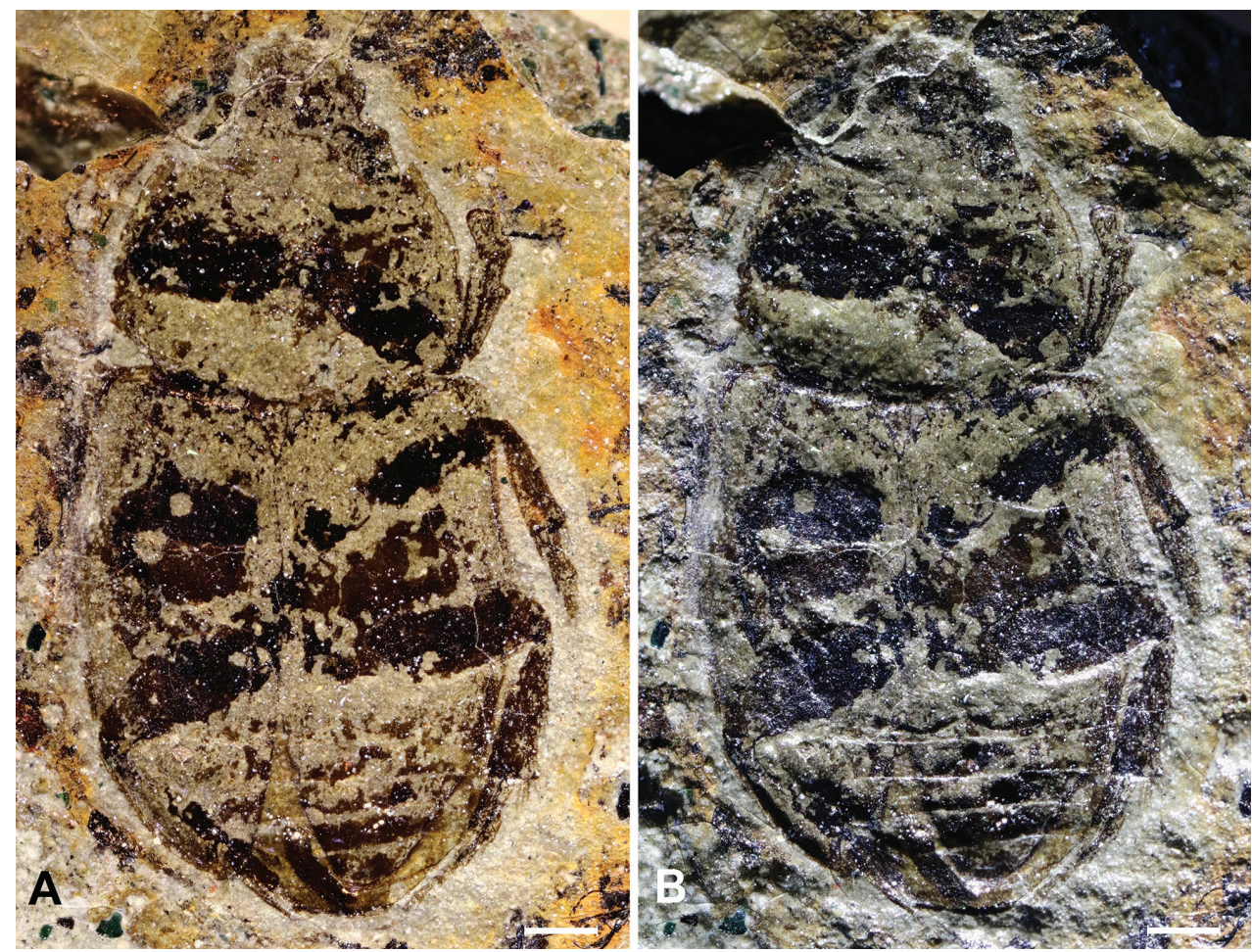

Figure 3. Ceafornotensis archratiras gen. and sp. n.: holotype BP/2/18654, general appearance. Micrographs taken under: $\mathbf{A}$ polarised light $\mathbf{B}$ low angle unpolarised light. Scale bar: $1 \mathrm{~mm}$.
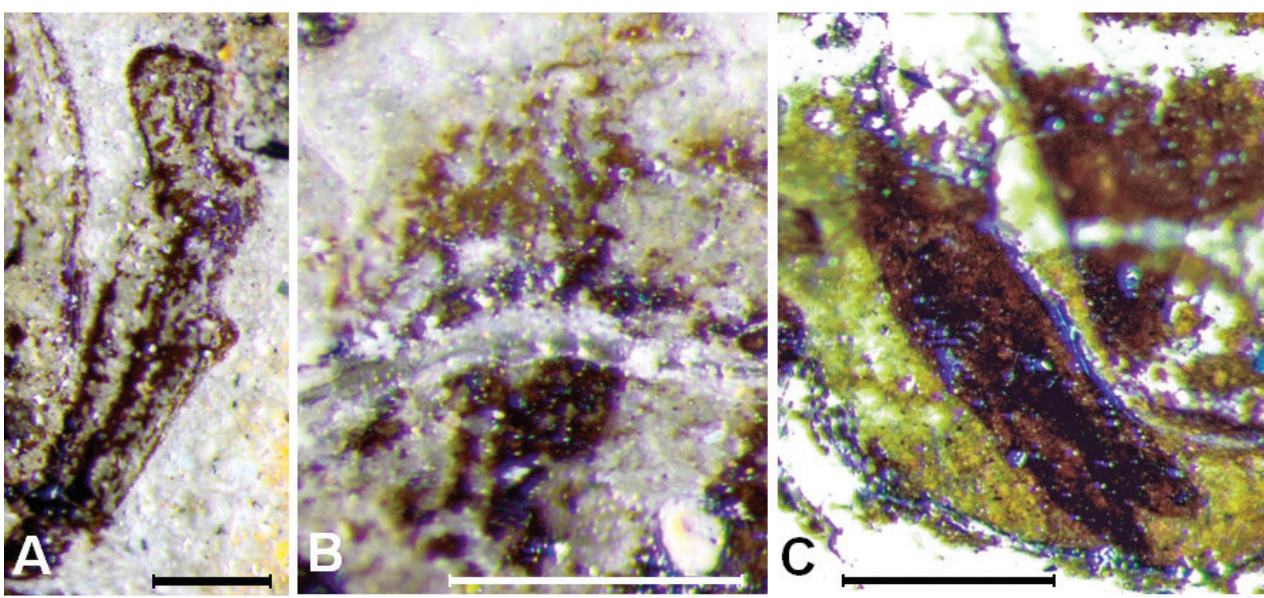

Figure 4. Ceafornotensis archratiras gen. and sp. n.: (A, B, C) holotype BP/2/18654, characters enlarged. Micrographs of: $\mathbf{A}$ right protibia $\mathbf{B}$ left mandible $\mathbf{C}$ aedeagus. Scale bar: $0.5 \mathrm{~mm}$. 


\section{Discussion}

Characters which pose some uncertainty in their interpretation are the mouthparts and the distal portion of the protibia. The mandibles and labrum of the Orapa fossil clearly extend beyond the clypeus which is considered the plesiomorphic condition (Scholtz et al. 1988). Krell (2006) however states that this extension could result from gaseous pressure or disarticulation during decay and therefore the degree to which the mandibles are exposed in the Orapa specimen could be exaggerated. There is evidence to suggest that the labrum may be broad and similar in width to the clypeus. The lateral margins of the labrum are however not distinct enough to be certain and the labrum could be the width of the intermandibular space.

The apex of the protibia (Figs 2, 4a) displays a well-defined 'lobe' which appears to abruptly truncate the apex whilst expanding it laterally on the inner margin. Damage or orientation could result in this unusual form although another possibility is that the apex is partially obscured by a superimposed structure. It is suggested that this could be the proximal segments of the protarsi, however, although the proximal segments of the meso- and metatarsi appear fairly broad and robust (segment 2 of the mesotarsus appears to have a 'scalloped' apical margin which may have accommodated stout spines), this condition would be particularly evident in the protarsi if this were the case. Adaptions of the protarsi are seen in some male melolonthines (Evans 2000) and superimposed impressions of what could be articulation of the first tarsal joint and apical teeth of the protibia give some support to this.

Alternatively, the form of protibae taken 'as is' could be a 'spade-like' fossorial adaption, possibly for digging in soft earth or sand. Some sand-inhabiting Pachysoma Macleay, 1821 species (wingless dung beetles) possess arcuate protibae which are widened on the inner margin; although their form is far more elongate and dentate. Arguably though, the dentate protibae of most scarbaeids are already fossorially adapted, for example in the Ochodaeidae (sand-loving scarabs), which possess no unique specialisation to their environment other than variation in the typical dentate condition. The more likely scenario then is that the distal 'profile' of the protibae in the Orapa fossil is not of its living form. If we accept that the specimen possesses no distinct adaptation, then the small, single tooth of the outer margin of the protibia, the lack of pronounced apical widening of the tibae, and the clypeus and head also not distinctly widened, would indicate that the beetle was not a strong digger (compared to dung beetles for example). This species may have lived much of its adult life above ground or in the upper soil and litter layer where bioturbation would produce a loose, non-compacted matrix. An alternative explanation could be that the form of the tibae was sexual dimorphic with females possessing a more fossorially adapted tibae to aid nest building, as is observed in the Lichnia Erichson, 1835, Lichninii (Hawkins 2006).

The form of the left mandible (Fig. 4b) (the right mandible partially obscured); a sclerotised apiculus (distal part of the mandible), terminating apically in a single tooth and teeth occurring proximally, is typical of several basal and derived taxa (Nel and Murray De Villiers 1988). The form does not appear indicative of specialised 
diets such as carrion (Hybosoridae) or dung feeding (Scarabaeinae, Aphodiinae) and therefore a phytophagous or saprophagous /fungivorous diet would seem most likely. If dietary preference was shared with extant adult melolonthines, then a strictly phytophagous diet should be expected which could include leaves, flowers or young fruits (Ritcher 1958). According to Nel and Scholtz (1990), the forms of mouthparts of extant melolonthines can be divided into five groups of which the mandible of the Orapa specimen most closely resembles group 2 . Functionally, this form is adapted for cutting and grinding plant matter, however, as the mandible also corresponds to a plesiomorphic form shared by other taxa, its dietary preference is unclear. A fungivorous (Scholtz and Chown 1996) or saprophagous (Cambefort 1991) diet, the suggested ancestral diets of adult scarabaeoidea, could be possible. However, estimates of the origin of the pleurostict crown group suggest that phytophagy emerged between 109 and 128 $\mathrm{Ma}$ (Ahrens et al. 2014) which gives some support to the proposal that the adult beetle may have fed on living plants. That the paleoenvironment of the inner crater was likely dominated by angiosperms (Bamford 1990) does at least indicate that a proportion of its sustenance, either through adult feeding or larval feeding on plant roots, humus or rotting wood, was likely derived from angiosperms, particularly if the specimen was an inhabitant of the crater environment.

According to estimated divergence times given by Ahrens et al. (2014), the Orapa specimen existed early in the radiation of the pleurostict scarabaeids and before the divergence of many of the extant melolonthine tribes and the subfamilies of the 'Higher Scarabaeidae' (Rutelinae, Dynastinae and Cetoniinae). The age of the Orapa specimen and its apparent basal positon in what is a very diverse and still poorly understood phylogeny (Jameson and Ratcliffe 2000), limits what can be inferred regarding its relationship to extent taxa. For instance, whether it represents a stem lineage either to the extant melolonthine tribes or other more derived groups is unknown. The Orapa specimen's relationship to angiosperm radiation is equally unclear although its existence prior to the apparent large radiation of pleurostict scarabs in the Tertiary may suggest that even the dominance of angiosperms, approximately $60 \%$ of species during the Turonian (Lidgard and Crane 1990), was not yet sufficient to drive a major radiation in the pleurosticts. Ahrens et al. (2014) suggest that this later radiation was the result of a large propagation in available niches brought about by increased angiosperm productivity and synergistic and self-propagating changes in litter and microbial conditions over wide biogeographical regions. This in turn corresponded with enrichment in pleurostict endosymbiotic gut microflora.

In summary, evidence is presented in support of the Orapa specimen as a basal member of the sub-family Melolonthinae. The phylogeny of the Melolonthinae is at present unresolved and probably paraphyletic. Assignment of fossil specimens to this group will therefore be problematic until further work is undertaken to address inconsistencies between morphological and molecular derived phylogenies. Further work on resolving the phylogenetic relationships of the basal taxa Phaenognathini and Lichniini is welcomed together with a greater understanding of the Melolonthinae 'grade' and how this might relate to other scarabaeid subfamilies. 


\section{Acknowledgements}

The work was funded by the DST-NRF Centre of Excellence in Palaeosciences funding initiative. I am grateful to Prof Marion Bamford, Dr Riaan Stals and the Wits Research Office for respectively providing equipment, specimens for comparative study, and additional research-related funding in support of this work.

\section{References}

Ahrens D (2006) The phylogeny of Sericini and their position within the Scarabaeidae based on morphological characters (Coleoptera: Scarabaeidae). Systematic Entomology 31: 113144. doi: $10.1111 / j .1365-3113.2005 .00307 . x$

Ahrens D, Schwarzer J, Vogler AP (2014) The evolution of scarab beetles tracks the sequential rise of angiosperms and mammals. Proceedings of the Royal Society of London B: Biological Sciences 281: 20141470. doi: 10.1098/rspb.2014.1470

Bai M, Ren D, Yang X (2011) Prophaenognatha, a new Aclopinae genus from the Yixian Formation, China and its phylogenetic position based on morphological characters (Coleoptera: Scarabaeidae). Acta Geologica Sinica 5: 984-993. doi: 10.1111/j.17556724.2011.00532.x

Bamford MK (1990) The Angiosperm Palaeoflora from the Orapa Pipe, Botswana. PhD thesis, University of the Witwatersrand, Johannesburg.

Brothers DJ, Rasnitsyn AP (2003) Diversity of Hymenoptera and other insects in the Late Cretaceous (Turonian) deposits at Orapa, Botswana: a preliminary review. African Entomology 11: 221-226.

Browne J, Scholtz CH (1998) Evolution of the scarab hindwing articulation and wing base: a contribution toward the phylogeny of the Scarabaeidae (Scarabaeoidea: Coleoptera). Systematic Entomology 23: 307-326. doi: 10.1046/j.1365-3113.1998.00059.x

Browne J, Scholtz CH (1999) A phylogeny of the families of Scarabaeoidea (Coleoptera). Systematic Entomology 24: 51-84. doi: 10.1046/j.1365-3113.1999.00067.x

Cambefort Y (1991) From Saprophagy to Coprophagy. In: Hanski I, Cambefort Y (Eds) Dung beetle ecology. Princeton University Press, New Jersey, 22-35.

Davis GL (1977) The ages and uranium contents of zircons from kimberlites and associated rocks. Extended Abstracts, 2nd International Kimberlite Conference. American Geophysical Union, Washington, DC. [Extended Abstracts]

Evans AV (2000) III Melolonthinae Samouelle 1819. In: Arnett Jr RH, Thomas MC (Eds) American Beetles, Volume I: Archostemata, Myxophaga, Adephaga, Polyphaga: Staphyliniformia, vol 2. CRC Press LLC, Boca Raton, 1-5.

Haggerty SE, Raber E, Naeser CW (1983) Fission track dating of kimberlitic zircons. Earth \& Planetary Science Letters 63: 41-50. doi: 10.1016/0012-821X(83)90020-1

Hawkins SJ (2006) A revision of the Chilean tribe Lichniini Burmeister, 1844 (Coleoptera: Scarabaeidae: Melolonthinae). Zootaxa 1266: 1-63. 
Jameson ML, Ratcliffe BC (2000) Series Scarabaeiformia Crowson 1960 (= Lamellicornia), Superfamily Scarabaeoidea Latreille 1802, Introduction. In: Arnett Jr RH, Thomas MC (Eds) American Beetles, Volume I: Archostemata, Myxophaga, Adephaga, Polyphaga: Staphyliniformia, vol 2. CRC Press LLC, Boca Raton, 1-5.

Krell F-T (2006) Fossil record and evolution of Scarabaeoidea (Coleoptera: Polyphaga). Coleopterists Society Monograph 5: 120-143.

Kuschel G, Oberprieler RG, Rayner RJ (1994) Cretaceous weevils from southern Africa, with description of a new genus and species and phylogenetic and zoological comments (Coleoptera: Curculionoidea). Entomologica scandinavica 25: 137-149. doi: 10.1163/187631294X00261

Lidgard S, Crane PR (1990) Angiosperm Diversification and Cretaceous Floristic Trends: A Comparison of Palynofloras and Leaf Macrofloras. Paleobiology 16: 77-93.

McKay IJ (1990) Cretaceous Carabidae (Coleoptera: Carabidae) from Orapa, Botswana. PhD thesis, University of the Witwatersrand, Johannesburg, South Africa.

McKay IJ (1991) Cretaceous Promecognathinae (Coleoptera: Carabidae): a new genus, phylogenetic reconstruction and zoogeography. Biological Journal of the Linnean Society 44: 1-12. doi: 10.1111/j.1095-8312.1991.tb00603.x

McKay IJ, Rayner RJ (1986) Cretaceous fossil insects from Orapa, Botswana. Journal of the Entomological Society of Southern Africa 49: 7-17.

McKenna DD, Farrell BD, Caterino MS, Farnum CW, Hawks DC, Maddison DR, Seago AE, Short AEZ, Newton AF, Thayer MK (2015) Phylogeny and evolution of Staphyliniformia and Scarabaeiformia: forest litter as a stepping stone for diversification of nonphytophagous beetles. Systematic Entomology 40: 35-60. doi: 10.1111/syen.12093

Nel A, Murray De Villiers W (1988) Mouthpart Structure in Adult Scarab Beetles (Coleoptera: Scarabaeoidea). Entomologia Generalis 13: 95-114. doi: 10.1127/entom.gen/13/1988/95

Nel A, Scholtz CH (1990) Comparative morphology of the mouthparts of adult Scarabaeoidea (Coleoptera). Entomological Memoir (no. 80). Department of Agricultural Development, Pretoria, 84 pp.

Nikolajev GV (1995) A new subfamily of Lamellicorn beetles (Coleoptera, Scarabaeidae) from the Lower Cretaceous of Transbaykalia and its phylogenetic relationships. Paleontological Journal 29: 185-191.

Nikolajev GV (1998) Pleurostict Lamellicorn Beetles (Coleoptera, Scarabaeidae) from the Lower Cretaceous of Transbaikalia. Paleontological Journal 32: 513-520.

Nikolajev GV (2007) Mezozoyskiy Etap Evolyutsii Plastinchatousykh (Insecta: Coleoptera: Scarabaeoidea). Kazak Universiteti, Almaty, 222 pp.

Ocampo FC, Mondaca J (2012) Revision of the scarab family Aclopinae Blanchard (Coleoptera: Scarabaeidae) in Argentina and Chile. Zootaxa 3409: 1-29.

Rasnitsyn AP, Brothers DJ (2007) Two new hymenopteran fossils from the mid-Cretaceous of southern Africa (Hymenoptera: Jurapriidae, Evaniidae). African Invertebrates 48: 193-202.

Rayner RJ (1987) March flies from an African Cretaceous springtime. Lethaia 20: 123-127. doi: 10.1111/j.1502-3931.1987.tb00769.x

Rayner RJ (1993) The Fossils from the Orapa Diamond Mine: A Review. Botswana Notes and Records 25: 1-17. doi: 10.2307/40979977 
Rayner RJ, Bamford MK, Brothers DJ, Dippenaar-Schoeman AS, McKay IJ, Oberprieler RG, Waters SB (1997) Cretaceous fossils from the Orapa Diamond Mine. Palaeontologia Africana 33: 55-65.

Rayner RJ, Waters SB, Mckay IJ, Dobbs PN, Shaw AL (1991) The mid-Cretaceous palaeoenvironment of central Southern Africa (Orapa, Botswana). Palaeogeography, Palaeoclimatology, Palaeoecology 88: 147-156. doi: 10.1016/0031-0182(91)90020-R

Ritcher PO (1958) Biology of Scarabaeidae. Annual Review of Entomology 3: 311-334. doi: 10.1146/annurev.en.03.010158.001523

Scholtz CH, Chown SL (1996) The evolution of habitat use and diet in the Scarabaeoidea: a phylogenetic approach. In: Pakaluk J, Slipinski SA (Eds) Biology, phylogeny and classification of Coleoptera: papers celebrating the 80th birthday of Roy A. Crowson, vol 2. Muzeum i Instytut Zoologii PAN, Warszawa, 355-374.

Scholtz CH, d'Hotman D, Evans AV, Nel A (1988) Phylogeny and systematics of the Ochodaeidae (Insecta: Coloeptera: Scarabaeoidea). Journal of the Entomological Society of Southern Africa 51: 207-240.

Smith ABT, Hawks DC, Heraty JM (2006) An overview of the classification and evolution of the major scarab beetle clades (Coleoptera: Scarabaeoidea) based on preliminary molecular analyses. Coleopterists Society Monograph 5: 35-46. doi: 10.1649/0010-065X(2006)60[ 35:AOOTCA]2.0.CO;2

Waters SB (1989) A cretaceous dance fly (Diptera: Empididae) from Botswana. Systematic Entomology 14: 233-241. doi: 10.1111/j.1365-3113.1989.tb00280.x 